AJ $\mathrm{H}$

Article history

Received : 08.08.2018

Revised : 08.11.2018

Accepted : 19.11.2018

Members of the Research Forum

Associated Authors:

${ }^{1}$ Department of Pomology and

Floriculture, College of Agriculture,

Vellayani, Thiruvananthapuram

(Kerala) India
Author for correspondence

A.V. Joseph

Department of Pomology and

Floriculture, College of Agriculture,

Vellayani, Thiruvananthapuram

(Kerala) India

Email : annjoevjoseph43@

gmail.com
THEASIAN JOURNAL OF HORTICULTURE

Volume 13 | Issue 2 | December, 2018 | 50-54

Visit us -www researchjournal co in
RESEARCH PAPER

DOI : 10.15740/HAS/TAJH/13.2/50-54

\title{
Characterization of ecotypes of Nendran banana (Musa AAB plantain subgroup)
}

\section{A. V. Joseph and S. Simi ${ }^{1}$}

ABSTRACT : The study on characterization of ecotypes of banana (Musa AAB Plantain subgroup) was undertaken in the Department of Pomology and Floriculture, College of Agriculture, Vellayani during April 2016- May 2017 with the objective to characterize the various ecotypes of plantain with respect to clonal characteristics and yield potential. The study revealed that considerable variability existed between the different ecotypes of plantain. The ecotypes varied significantly with respect to all the clonal characters studied, except the number of ridges. Mettupalayam Nendran produced the highest yield but it had long duration. Zanzibar and Big Ebanga were superior in terms of finger characteristics.PSI (Pedicel Strength Index) was the highest in Mettupalayam Nendran (3.17) which was significantly higher than all other clones. The genotypes having high yield like Mettupalayam Nendran, Myndoli etc can be used in further crop improvement programmes to develop high yielding Nendran types.

KEY WORDS : Banana, Nendran, Plantain, Ecotype, Evaluation, Yield characters, Clonal characters

HOW TO CITE THIS ARTICLE : Joseph, A.V. and Simi, S. (2018). Characterization of ecotypes of Nendran banana (Musa AAB plantain subgroup). Asian J. Hort., 13(2) : 50-54, DOI : 10.15740/HAS/ TAJH/13.2/50-54. Copyright@2018 : Hind Agri -Horticultural Society 